\title{
Factors Influencing Industrialized Building System (IBS) Project Performance: A Systematic Review
}

\author{
Yusmin Jaffar ${ }^{1 *}$, Chia Kuang Lee ${ }^{2}$ \\ 1, 2 Project Management Program, Faculty of Industrial Management, Universiti Malaysia Pahang, Lebuhraya Tun Razak, 26300 Gambang, Kuantan, \\ Pahang Darul Makmur.
}

\begin{abstract}
Industrialized Building System (IBS) is a form of construction with focused processes comprise of methods, products and a set of connected components which work together to achieve objectives. Malaysian construction industry is one of contributors towards the development of the country. To ensure vitality of construction performance, utilization and application of IBS is the right system to shift to from the current conventional construction method. Adaptability of IBS in Malaysia's construction industry is very low due to various limitations and barriers. To better understand IBS, this paper performs a systematic review of studies underpinning the factors influencing IBS success. From a total of 111 articles reviewed in this paper, 16 factors were highly mentioned, such as knowledge and expertise, cost of construction, training, Communication, Lean Construction, Government Policies, Contractors' Satisfaction, Integration of Resources, Utilization of Software, Market Factor, On-site Management, Technical factor, Integrated Processes Assessment, Management Factor, Payment Issues, and Employee Empowerment. These factors significantly influence IBS project performance.
\end{abstract}

ARTICLE HISTORY

Received: $11-06-2020$

Accepted: $20-07-2020$

\section{KEYWORDS}

Industrialized building system (IBS);

Construction Performance; Construction integrity; Pre-fabrication; IBS Project Performance; IBS integrity

\section{INTRODUCTION}

Introduction of modern technologies as well as building system innovation development has contributed significant influence towards many aspects of construction industry. Construction industry in Malaysia benefited well through fundamental transformation by implementing IBS throughout the whole industry. The application of the Industrialized Building System (IBS) in Malaysia started in 1963 but still, participation and adoption of IBS in the local construction industry is relatively low compared to other developed countries (Nawi et al., 2015, Jabar et al., 2019). In 1999, "The IBS Strategic Plan" was launched. Following that, the IBS Roadmap 2003-2010 was introduced in 2003 to promote IBS in the effort to reduce dependency on foreign site operatives, improve governance and integrity of management on site, whilst advancing towards a more systematic approach to construction (Jabar et al., 2019). In 2008, government has made it mandatory for every contractor in Malaysia to achieve a minimum of $70 \% \mathrm{IBS}$ content for every project, thereafter replacing the IBS Roadmap 2003-2010 to IBS Roadmap 2011-2015 (Jabar et al., 2019).

These plans were to support development towards a more extensive IBS implementation among construction projects in Malaysia. Malaysia houses a competitive construction environment, yet very labour intensive, which makes the Malaysian Government continuously encourage application of modern methods of construction to achieve a healthy and sustainable construction industry environment (Nawi et al., 2019). Being among the main contributor towards the development of the country, the construction industry in Malaysia need to ensure performance of the industry meets minimum standards as well as client requirements, and adhering to standards, integrity and governance on site. To ensure the vitality of performance within the construction industry, construction players are encouraged to shift towards modern method of construction through the utilization and application of IBS (Yunus et al., 2016). IBS is an alternative method to replace conventional construction to achieve sustainable deliverables (Yunus et al., 2019).

In conventional methods of construction, building components are prefabricated on site and require intense labour as well as high cost for raw material transportation (Jabar et al., 2019; Rubio-Romero et al., 2014; Yip et al., 2019). As generally known, intense activities are the most natural aspects of conventional on-site work which can cause a bad environment such as traffic chaos, noise and air pollution (Akmam et al., 2018; Yunus et al., 2019). By removing some or most of the work off-site, it will greatly contribute towards harmonization of development with surrounding environment. The application of off-site prefabrication and modularization can also significantly contribute towards productivity gains, decreasing labour requirements, as well as improving working condition not just among workers who are directly involved in the project, but also its surrounding environment (Akmam et al., 2018; Yip et al., 2019; Yunus et al., 2019). IBS is a form of system or a technique to manufacture components for construction of structures in a controlled environment. However, how one defines and perceives IBS can differ according to various reasons.

The objective of this paper is to highlight factors that can significantly influence IBS project performance through systematic review of articles. Articles will be divided into themes of IBS and factors will be derived from these themes. The highlighted factors will then be discussed in terms of which factor is the most influential based on the most mentioned factor through careful review of each articles. 


\section{LITERATURE REVIEW}

To understand the concept used in this paper, this section will explain and discuss key concepts, definitions and previous studies related to the research investigation.

\section{Industrialized Building System (IBS)}

Industrialized Building System (IBS) is an engineering innovation to deter most influential disadvantages of conventional methods of construction in order to boost project performance. There are several widely used performance indicators for IBS. One of it is construction cost for construction activities.

Construction activities requires high initial investment capital designated for machineries, steel mould, foreign technology, transportation and the wages of skilled workers for the installation process (Azman et al., 2012; Baharuddin et al., 2016; Kamar et al., 2014; Zakari et al., 2017). Dependency on unskilled workers may save some costs, but inefficient conventional process will eventually cause delay in projects, waste materials, lead to low quality and efficiency in projects and totally increase financial losses (Taherkhani et al., 2019). The early stage of IBS implementation requires a huge amount of cost due to the paid-up capitals and maintenance of machineries (Baharuddin et al., 2016; Nasir etal., 2016; Tamrin et al., 2016). Cost of construction is one of the major influential factors that can directly alter performance of IBS project (Kamar et al., 2014; Xue et al., 2018). High cost factor involves cost for the purchase of new machinery, mould-manufacturing, tax for machinery and equipment imported from overseas and employee retraining cost (Kamar et al., 2012; Nawi et al., 2015a). When venturing into the world of construction, cost became a part of project where minimising it is crucially of importance to achieve successful end. Besides high initial capital requirement, cost can be wasted during construction processes caused by incompetence as well as lack of proper management (Yip et al., 2019).

Knowledge and expertise in IBS play a major role towards the performance of IBS projects (Kamar et al., 2014). Successful IBS implementation requires extensive knowledge of processes, design, and manufacturing (Baharuddin et al., 2016; Rashidi \& Ibrahim, 2017). Implementation of IBS requires expertise to delegate and foster cooperation between the key players of the project to ensure the success of IBS projects (Abas et al., 2014; Nasir et al., 2016). Lack of adequate knowledge and expertise among clients, designers, as well as constructors can adversely impact the project (Baharuddin et al., 2016; Kamar et al., 2012; Nawi et al., 2015b). Study conducted by Zakari et al (2017) also support the notion of major barrier in IBS performance is lack of research and inadequate knowledge of IBS.

Communication greatly affects the performance of construction project. Failure to adhere to effective communication can cause problems such as double handling, time delay, as well as storage problems which will later present negative impact towards cost of operation, quality, and project completion duration. Effective communication is crucial in order to efficiently exercise control over all processes to ensure they perform accurately, appropriately, and at the right instance (Pozin et al., 2017; Pozin et al., 2019). In a typical construction project, information can be in many forms including drawings, contracts, reports, charts and worksheets (Nasir et al., 2016). Construction projects consists of various parties (owner, architects, engineers, contractors), decisions and data, and a long set of processes starting with the initial idea and followed by a feasibility study, design, construction and operation and maintenance works.

Information flow is important. Poor communication between stakeholders would cause unnecessary repetition and delay, caused by ineffective exchange of information. These problems will lead to the incur of high expenses and extra time to remedy the damages in project (Nasir et al., 2016). Therefore, interconnected of communication between people involved in the projects should be given serious consideration. According to Kamar et al (2010), a good project communication should be able to assure seamless information and instructions flow to carry out construction activities across the project phases.

Training to inculcate sufficient knowledge and awareness in IBS construction does not solely rest on the contractors. The authorities need to harness such knowledge as well. Many local authorities are depicted to be lack of knowledge and are unfamiliar with modular coordination and standardization concept related with IBS design and assembling process (Zakaria et al., 2017). This has significantly slowed down building approval and result in unnecessary delay in the development process. Local construction authorities tend to misunderstand IBS guidelines adding to further delays in approval (Zakaria et al., 2017). Zakari et al (2017) also found that building regulation as well code and standard are factors that can highly influence performance of IBS and can be seen to fit to authorities instead of the contractors. Therefore, instead of having contractors to acquire sufficient training to better understand and utilize IBS, the local construction authorities also require appropriate training to optimize the performance of IBS.

Government policies have been prominent in promoting new construction techniques or products in the construction industry, simply because the government is one of the biggest clients in the construction industry (Nawi et al., 2012). The role of government plays significant role in IBS project performance and can vary in forms. Among government's policies that positively contribute towards IBS application increment in Malaysia is through the IBS Roadmap 2011-2015 where every project is mandatory to achieve a minimum of $70 \%$ IBS content (Jabar et al., 2019). A study conducted by Yunus et al (2019) highlighted the economic reality of 'rising energy cost' where contractors will have to bear and participate whether they agree or not in the effort to provide deliverables as well as to fulfil their own interest. Yunus et al (2019) further explains that the role of government is crucial as far as establishing mandatory regulations, or building codes in order to ensure every parties involve in a particular project will actively take part towards sustainable delivery of project. Lack of government's policies enforcement can be viewed where there is no specific IBS building regulation or standard guidelines for contract documents or procurement systems in terms of tendering, design, construction and operation of a 
project pertaining to IBS (Baharuddin et al., 2016). Nasir et al (2016) also indicated that financial problems stemming from building materials as well as land costs from have seriously impacted and delayed the completion of IBS projects.

Resources is critical in construction management. Evidence of below par performance in construction projects has been recognized by government and industry bodies around the world. This problem has been partially caused by variability in resource availability and shortage of specialized contractors (Arashpour et al., 2018). Process integration and cross-training can facilitate the flow of work within prefabrication networks because multi-skilled resources are not limited to perform single tasks and can operate over a production zone or potentially the whole network (Arashpour et al., 2018). In the construction industry, the term of 'integration' has been used to describe a collaborative work environment culture created by all participants involved in a project either by individuals or organizations. This culture is required in order to bring the various organizations that make up the project delivery team to work together more effectively as a single unit.

Process integration: IBS is an integrated process involving all subsystems, components, manufacturing and construction processes, and which all requires efficient management (Jabar et al., 2019). Design, production, and onsite erection are strongly interrelated which can be viewed as part of an integrated process that requires planning and coordination (Aljawadi et al., 2019). Integration processes across the whole project must undergo certain level of assessment in order for contractor to achieve high level of efficiency and synergy between processes as well as to avoid future unnecessary costs. Problems such as changing orders, delays in production or construction and budget overrun during implementation are among factors that influence IBS project delivery (Yunus et al., 2012).

Other related performance indicators for IBS are management and lean construction: IBS consist of integrated processes scattered throughout the whole period and project itself. Processes involved subsystems in manufacturing, components, as well as the construction process itself (Jabar et al., 2019). Jabar et al (2019) further pressed that in order for all the systems to be executed in an efficient and appropriate manner, management factor is an inevitable variable. Effective management can significantly increase efficiency of each system as well as subsystems integrated within a particular project. Lean means getting the right things to the right place, at the right time, and in the right quantity while minimizing waste and being flexible and open to change (Nahmens and lkuma, 2012). The prevailing goal of lean production is to deliver value to all stakeholders, including internal and external customers, and to eliminate waste (Nahmens and Ikuma, 2012). In construction, the application of lean production stems from the creation of value through the conversion of inputs into finished products with a systematic flow and process of production. Lean construction also refers to the adaptation of lean production principles and practices to the construction industry. One of the key focus of lean construction is waste elimination from construction processes, while simultaneously creating a culture within the company of continuous improvement (Nahmens and Ikuma, 2012).

\section{METHODOLOGY}

To achieve the objective of this paper, a systematic review was performed in order to collect and obtain detailed evidence for the impact of the important factors. The systematic review approach was adopted based on a study by Lee et al., (2016) which consists of 5 basic steps of doing systematic review.

\section{Step 1: Identifying Keywords For Review}

Keywords relevant for the systematic review were identified. A total of 6 most appropriate keywords were identified and used to fulfil the requirement of the study. The 6 keywords are "IBS", "Industrialized Building System", "pre-fabrication", "modern method construction", "off-site construction", and "industrialized building system (IBS)".

\section{Step 2: Selecting Data Source}

Specific data source was selected to perform the search using all 6 previously identified keywords. Search was made based on the subject area of engineering as IBS is mainly an engineering method of construction innovation. Scopus search engine was used to generate results from keywords identified in previous step. In Scopus, the search was made considering 'Title/Abstract/Keywords' and it generated a total number of 11,376 documents from various subject areas, document types and also other related keywords.

\section{Step 3: Preliminary Search}

Search was done using all the keywords obtained from the first step within the subject area indicated in the second step. 'Scopus' search engine was used to perform a comprehensive search as well as systematic review on IBS.

\section{Step 4: Assessing The Quality Of The Studies}

Results generated through Scopus search engine were further filtered to obtain the most suitable articles in order to achieve the objective. Total of 11,376 documents were trimmed down to 111 documents to be synthesized to obtain factors that influence performance of IBS project.

\section{Step 5: Summarizing The Evidence}

All 111 total filtered documents were then synthesized and grouped into themes consisting of what factors were the articles mostly mentioned or highly discussed. From total of 111 articles, 73 corresponds towards factors influencing IBS project performance. The remaining 38 articles were studies that were not directly related towards IBS project performance. These rejected articles were studies 
of 'Mechanics of Materials' which deals with behaviour of solid objects, in this context, the materials used in construction. The papers mostly discussed on various methods and results of calculating stresses and strains in structural members rather than relating to the main objective of this paper. Therefore, from total 111 articles, only 73 were deemed useful which mainly discussed on factors relating to IBS project performance.

Step 6: Interpreting Findings, Includes Synthesizing

Articles obtained were then interpreted and synthesized. As a result, 16 factors were classified under the theme of 'Factors influencing IBS project performance'. The 16 factors were then described in detail of what and how much does the factor itself influence performance of particular IBS project.

\section{RESULTS}

\section{Identifying Keywords For Review}

Industrialised Building System (IBS) is the term coined by the government and industry in Malaysia to represent the construction industry and the application of the prefabrication method in building construction (Kamar et al., 2012). IBS can be defined as a construction technique where the manufacturing of components is made in a controlled environment, on or off site, and which involved transportation, positioning and assembling of the components into a structure without using extensive extra site works (Nawi et al., 2015a). IBS can be referred to prefabrication, mass production, standardized components and design using modular coordination (Musa et al., 2016). In Malaysia, IBS is defined as a construction technique where components in projects are manufactured off-site, and then transported to site and assembled with minimum amount of work. In Singapore, IBS refers to manufacturing and construction systems of all structures including infrastructure. IBS is also a technique suited to overcome disadvantages of current conventional methods of construction which can also be referred to as a modern method construction. Keywords that appropriately define the range in IBS used in this review are: "IBS", "Industrialized Building System", "pre-fabrication", "modern method construction", "off-site construction", "industrialized building system (IBS)".

\section{Selecting Data Source}

For this particular review, documents will be selected under engineering themes only. Search engine 'Scopus' was chosen as it houses the largest abstract and citation databases for peer-reviewed journals, books, and conference proceedings (Lee et al., 2016). Using the keywords addressed from the first step, searches were made in the 'Title/Abstract/Keywords' method of search in the Scopus search engine.

\section{Preliminary Search}

Preliminary search was made using all the keywords obtained from the first step within the subject area indicated in the second step. 'Scopus' search engine was used to perform a comprehensive search as well as systematic review on IBS. Scopus is also widely known to perform much better than other world-known search engines such as Google Scholar, Web of Science and also PubMed in terms of coverage and accuracy. Comprehensive searches were done under 'Title/Abstract/keyword' using keywords such as "IBS", "Industrialized Building System", "pre-fabrication", "modern method construction", "off-site construction", "industrialized building system (IBS)". Preliminary search generated a total of 11,376 documents. The code is as follows:

(TITLE-ABS-KEY ("IBS") OR TITLE-ABS-KEY ("industrialised building system") OR TITLE-ABS-KEY ("prefabrication") OR TITLE-ABS-KEY ("modern method construction") OR TITLE-ABS-KEY ("off-site construction") OR TITLE-ABS-KEY ("industrialized building system (IBS)")

\section{Assessing The Quality Of The Studies}

From the total number of 11,376 generated documents, the search was restricted to subject area of engineering only as the rest of the subject area refers to medical and psychology area of subject matter. A total of 656 documents related to the keywords were generated. In order to achieve a more focused and specific search result, the 656 documents generated were filtered further by limiting the search results into journals only as well as into only document type such as: article, review, and conference paper. Limitations were also imposed towards specific keywords only such as "Off-site Construction", "Industrialized building system (IBS)", "Industrialized Building System", "Industrialised Building System", "Industrialised Building Systems", Prefabrication", "Industrialized Building Systems (IBS)", "Malaysian Construction Industry", "Prefabricated Construction", and "Industrialized Buildings". The full code is shown as follows:

( TITLE-ABS-KEY ( "IBS" ) OR TITLE-ABS-KEY ( "industrialised building system" ) OR TITLE-ABS-KEY ( "pre-fabrication" ) OR TITLE-ABS-KEY ( "modern method construction" ) OR TITLE-ABS-KEY ( "off-site construction" ) OR TITLE-ABS-KEY ( "industrialized building system (IBS)" ) ) AND ( LIMIT-TO ( SUBJAREA, "ENGI" )) AND ( LIMIT-TO ( SRCTYPE, "j" )) AND ( LIMIT-TO ( DOCTYPE, "ar") OR LIMIT-TO ( DOCTYPE, "re" ) OR LIMIT-TO ( DOCTYPE, "cp")) AND ( LIMIT-TO ( EXACTKEYWORD , "Off-site Construction" ) OR LIMIT-TO ( EXACTKEYWORD , "Industrialised Building System (IBS)" ) OR LIMIT-TO ( EXACTKEYWORD, "Industrialized Building System" ) OR LIMIT-TO ( EXACTKEYWORD, "Industrialised Building System" ) OR LIMIT-TO ( EXACTKEYWORD, "Industrialised Building Systems" ) OR LIMIT-TO ( EXACTKEYWORD , "Prefabrication") OR LIMIT-TO ( EXACTKEYWORD, "Industrialized Building Systems (IBS)" ) OR LIMIT-TO (EXACTKEYWORD "Malaysian Construction Industry" ) OR LIMIT-TO ( EXACTKEYWORD, "Prefabricated Construction" ) OR LIMIT-TO ( EXACTKEYWORD, "Industrialized Buildings"). Table 1 and Figure 1 shows the list of 111 articles from a total of 46 retrieved journals. 
Table 1: Retrieved Journals

Journals

Articles

Accident Analysis and Prevention

Advanced Science Letters

Architectural Engineering and Design Management

ARPN Journal of Engineering and Applied Science

Automation in Construction

Building and Environment

Building Engineer

Computers and Concrete

Concrete Precasting Plant and Technology

Construction History

Construction Innovation

Construction Managements and Economics

Dams and Reservoirs

Earthquake Engineering and Engineering Vibration

Electrical Journal of Information Technology in Construction

Energy and Buildings

Engineering, Construction and Architectural Management

Frontiers of Architectural Research

IES Journal Part A: Civil and Structural Engineering

International Journal of Housing Science and Its Applications

International Journal of Applied Engineering Research

International Journal of GEOMATE

Journal if Architectural Engineering

Journal of Civil Engineering and Management

Journal of Cleaner Production

Journal of Computing and Engineering

Journal of Construction Engineering and Management

Journal of Engineering Science and Technology

Journal of Infrastructure Systems

Journal of Management in Engineering

Journal of Robotics and Mechatronics

Journal of The Institution of Engineers (India): Architectural Engineering Division

Jurnal Teknologi

KSCE Journal of Civil Engineering

7
1

Malaysian Construction Research Journal

Open Construction and Building Technology Journal

Proceedings of Institution of Civil Engineers: Management, Procurement and Law

Proceedings of Institution of Civil Engineers: Waste and resource Management

Proceedings of Institution of Civil Engineers: Engineering Sustainability

Revista Tecnica de la Faculdad de Ingenieria Universidad del Zulia

Stahlbau

Steel and Composite Structure

Structural Design of Tall and Special Buildings

Structural Engineering International: Journal of the International Association for Bridge and Structural

Engineering (IABSE)

Structural Survey

International Journal of Interactive Mobile Technologies

TOTAL

1 112 


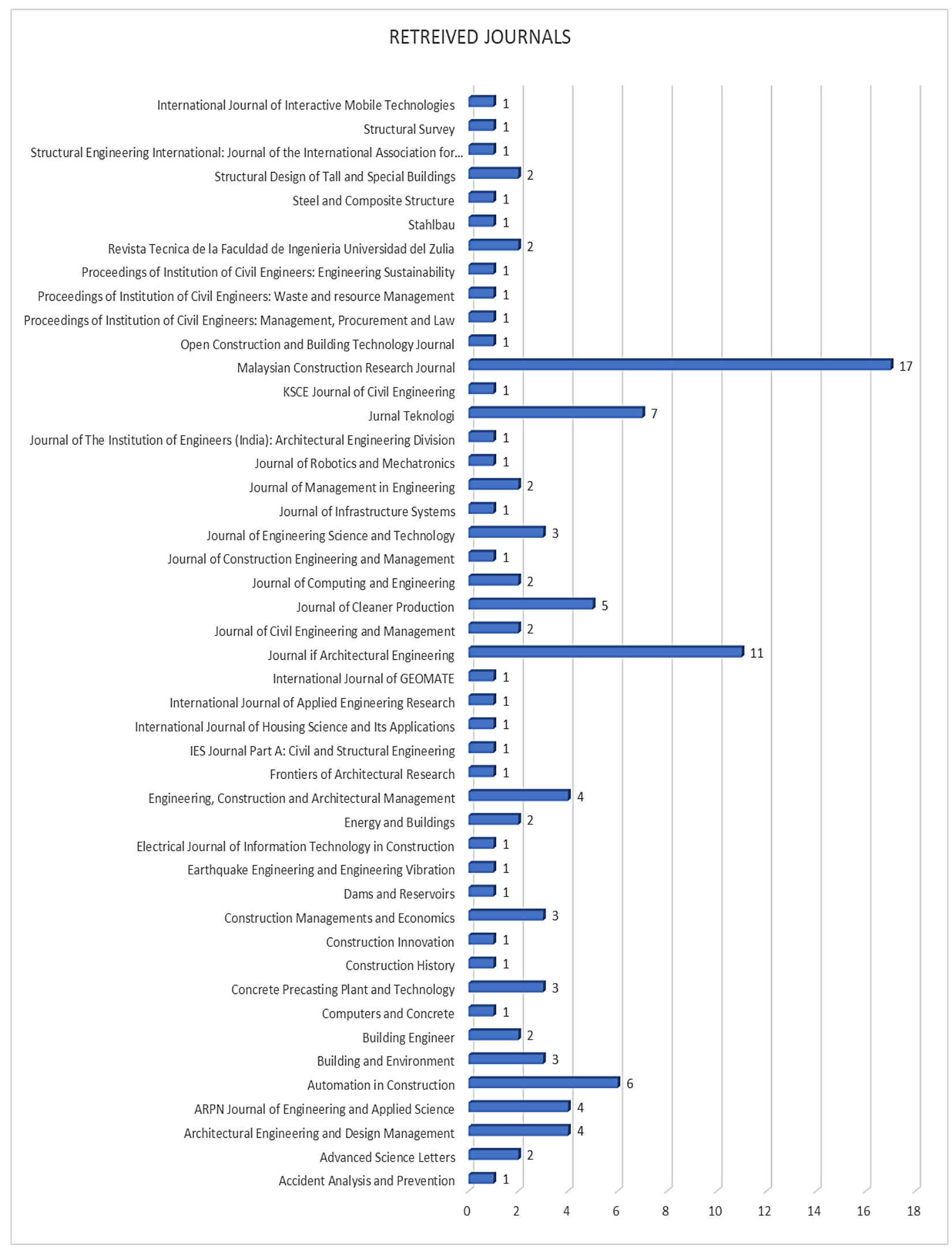

FIGURE 1: Retrieved Journals 
Table 2: Filtered Articles Journals

Articles

Accident Analysis and Prevention 1

$\begin{array}{ll}\text { Advanced Science Letters } & 1\end{array}$

Architectural Engineering and Design Management 3

ARPN Journal of Engineering and Applied Science

Automation in Construction 3

Betonwerk und Fertigteil-Technik/Concrete Precasting Plant and Technology 1

$\begin{array}{ll}\text { Building and Environment } & 3\end{array}$

\begin{tabular}{|c|c|}
\hline Construction History & 1 \\
\hline Construction Innovation & 1 \\
\hline Construction Managements and Economics & 2 \\
\hline Earthquake Engineering and Engineering Vibration & 1 \\
\hline Energy and Buildings & 1 \\
\hline Engineering, Construction and Architectural Management & 3 \\
\hline Frontiers of Architectural Research & 1 \\
\hline International Journal of Housing Science and Its Applications & 1 \\
\hline International Journal of Applied Engineering Research & 1 \\
\hline International Journal of Technology & 1 \\
\hline International Journal of GEOMATE & 2 \\
\hline Journal if Architectural Engineering & 6 \\
\hline Journal of Civil Engineering and Management & 1 \\
\hline Journal of Cleaner Production & 4 \\
\hline Journal of Engineering Science and Technology & 3 \\
\hline Journal of Infrastructure Systems & 1 \\
\hline Jurnal Teknologi & 7 \\
\hline KSCE Journal of Civil Engineering & 1 \\
\hline Malaysian Construction Research Journal & 12 \\
\hline Open Construction and Building Technology Journal & 1 \\
\hline Procedia - Social and Behavioral Sciences & 1 \\
\hline Proceedings of Institution of Civil Engineers: Management, Procurement and Law & 1 \\
\hline Revista Tecnica de la Faculdad de Ingenieria Universidad del Zulia & 2 \\
\hline Structural Survey & 1 \\
\hline International Journal of Interactive Mobile Technologies & 1 \\
\hline & 73 \\
\hline
\end{tabular}

\section{Summarizing The Evidence}

Step 5 aims to analyse and synthesize the content of the shortlisted 73 articles. All articles related to IBS were analysed qualitatively based on careful interpretation for each individual article. The synthesized themes represent 'Factors Influencing Successful IBS Implementation' and numbers of citations used to back up each factors as shown in Table 2. 
Table 3: Synthesized IBS Success Factors

\begin{tabular}{|c|c|c|}
\hline Factors & Number of Citations & $\begin{array}{l}\text { Number of } \\
\text { Journals }\end{array}$ \\
\hline Cost of Construction & 14 & 9 \\
\hline Knowledge and expertise & 10 & 7 \\
\hline Communication & 7 & 5 \\
\hline Training & 6 & 5 \\
\hline Government Policies & 5 & 5 \\
\hline Integration of Resources & 4 & 4 \\
\hline Integrated Processes Assessment & 3 & 3 \\
\hline Management Factor & 2 & 2 \\
\hline Lean Construction & 1 & 1 \\
\hline Contractors' Satisfaction & 1 & 1 \\
\hline Utilization of Software & 1 & 1 \\
\hline Market Factor & 1 & 1 \\
\hline On-site Management & 1 & 1 \\
\hline Technical factor & 1 & 1 \\
\hline Payment Issues & 1 & 1 \\
\hline Employee Empowerment & 1 & 1 \\
\hline
\end{tabular}

Interpreting Findings

This step synthesizes the factors that significantly influence the performance of IBS projects from the filtered 44 articles generated from previous steps. Table 3 shows the factors that were mentioned in all 67 journals. The factors were rated based on frequency percentage of the particular factor.

\section{DISCUSSIONS}

This section presents and synthesizes all 16 factors influencing the IBS project performance as stated in Table 3.

Table 4: List of Factors, Authors, and Journals

No.

FACTOR

AUTHOR JOURNAL

1. Cost of Azman, et al., (2012) Malaysian Construction Research Journal

Construction

Baharuddin et al., (2016)

Revista Tecnica de la Facultad de Ingenieria Universidad del Zulia

Hong et al., (2018)

Kamar et al., (2014) Journal of Cleaner Production

Journal of Engineering Science and Technology

Journal of Engineering Science and Technology

Kamar et al., (2012)

ARPN Journal of Engineering and Applied Sciences

Nasir et al., (2016)

ARPN Journal of Engineering and Applied Sciences

AENSI Journals

Nawi et al., (2015a)

Jurnal Teknologi

Nawi et al., (2017)

Shamsuddin et al., (2015)

Revista Tecnica de la Facultad de Ingenieria Universidad del Zulia Journal of Cleaner Production

International Journal of GEOMATE

Tamrin et al., (2016) Jurnal Teknologi

Xue et al., (2018)

Jurnal Teknologi 


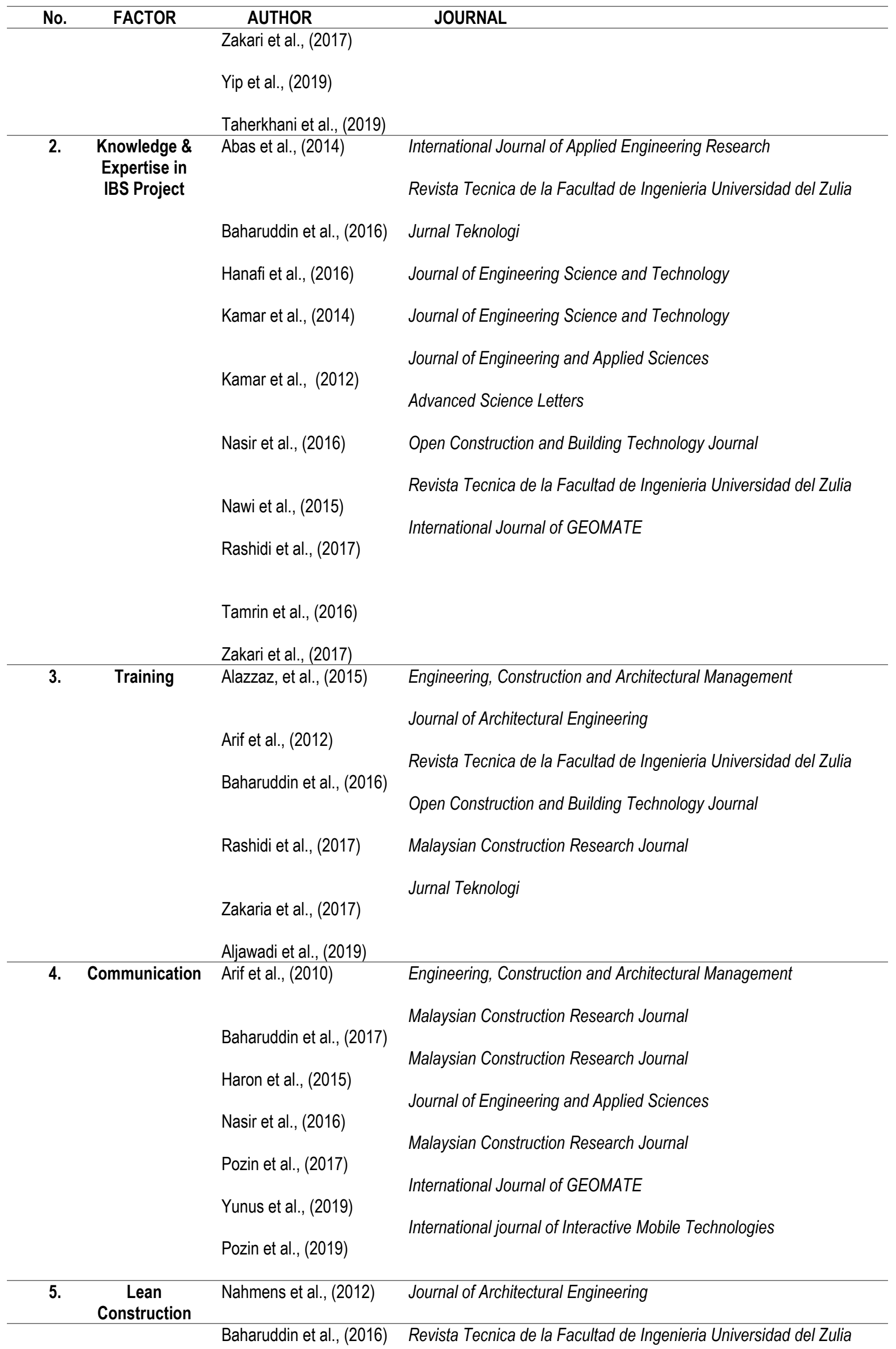




\begin{tabular}{|c|c|c|c|}
\hline No. & FACTOR & AUTHOR & JOURNAL \\
\hline 6. & $\begin{array}{l}\text { Government } \\
\text { Policies }\end{array}$ & $\begin{array}{l}\text { Nawi et al., (2012) } \\
\text { Yunus et al., (2019) } \\
\text { Nasir et al., (2016) }\end{array}$ & $\begin{array}{l}\text { Malaysian Construction Research Journal } \\
\text { International Journal of GEOMATE } \\
\text { ARPN Journal of Engineering and Applied Sciences } \\
\text { International Journal of Technology }\end{array}$ \\
\hline & & Jabar et al., (2019) & \\
\hline 7. & $\begin{array}{l}\text { Contractor's } \\
\text { Satisfaction }\end{array}$ & Yunus et al., (2016) & ARPN Journal of Engineering and Applied Sciences \\
\hline 8. & $\begin{array}{l}\text { Integration of } \\
\text { Resources }\end{array}$ & $\begin{array}{l}\text { Nawi et al., (2015b) } \\
\text { Nawi et al., (2014) }\end{array}$ & $\begin{array}{l}\text { Architectural Engineering and Design Management } \\
\text { Malaysian Construction Research Journal } \\
\text { Journal of Engineering Science and Technology } \\
\text { Malaysian Construction Research Journal }\end{array}$ \\
\hline & & Nawi et al., (2011) & \\
\hline 9. & $\begin{array}{l}\text { Utilization of } \\
\text { Software }\end{array}$ & Vernikos et al., (2014) & $\begin{array}{l}\text { Proceedings of Institution of Civil Engineers: Management, } \\
\text { Procurement and Law }\end{array}$ \\
\hline 10. & Market Factor & Luo et al., (2015) & Engineering, Construction and Architectural Management \\
\hline 11. & $\begin{array}{c}\text { On-Site } \\
\text { Management }\end{array}$ & Luo et al., (2015) & Engineering, Construction and Architectural Management \\
\hline 12. & $\begin{array}{l}\text { Technical } \\
\text { Factor }\end{array}$ & Luo et al., (2015) & Engineering, Construction and Architectural Management \\
\hline 13. & $\begin{array}{l}\text { Integrated } \\
\text { Assessment } \\
\text { Processes }\end{array}$ & $\begin{array}{l}\text { Yunus et al., (2012) } \\
\text { Jabar et al., (2019) } \\
\text { Aljawadi et al., (2019) }\end{array}$ & $\begin{array}{l}\text { Construction Innovation } \\
\text { International Journal of Technology } \\
\text { Jurnal Teknologi }\end{array}$ \\
\hline 14. & $\begin{array}{l}\text { Management } \\
\text { Factor }\end{array}$ & $\begin{array}{l}\text { Ismail et al., (2012) } \\
\text { Jabar et al., (2019) }\end{array}$ & $\begin{array}{l}\text { Procedia - Social and Behavioral Sciences } \\
\text { International Journal of Technology }\end{array}$ \\
\hline 15. & Payment Issues & Nawi et al., (2017) & AENSI Journals \\
\hline 16. & $\begin{array}{c}\text { Employee } \\
\text { Empowerment }\end{array}$ & Alazzaz et al., (2015) & Engineering, Construction and Architectural Management \\
\hline
\end{tabular}

\section{Factors Influencing Successful IBS Implementation}

A total of 16 influencing factors were derived from the overall 73 reviewed articles. Cost of construction was discussed the most, followed by knowledge and expertise in second. Communication factor positioned at third and training resides on fourth most discussed factors influencing the IBS project performance. Government policies were fifth, integration of resources sixth, integrated processes assessment seventh, and management factor placed eighth. The other factor stays the same at ninth rank with each being cited only once per factor.

\section{Cost Of Construction}

In order to ensure optimum and continuous performance, periodical financing is one alternative to support utilization of tasks. Due to the challenging nature of the construction industry, most construction companies face poor financial status and are unable to support and fund their projects (Kamar et al., 2012; Nasir et al., 2016). To achieve a well-organized IBS project, it requires specific type of equipment and machinery to produce the required component and in some cases, projects have to limit the amount of investment because the cost is too high and unbearable (Nasir et al., 2016). Yip et al. (2019) suggested for construction companies to integrate simulation process in their design phase in the effort towards minimising costs caused by errors or any other significant factors. 


\section{Cost Estimation Models}

The traditional type of cost estimation models continues to be in widespread use irrespective of their organizational type and size. An appraisal or review of the cost estimation practices in IBS construction projects is vital in order for IBS being well placed, and accordingly evolve with the various innovations that transpire within the construction industry (Shamsuddin et al., 2015). Existing appraisal must also be re-strategized to take advantage of the various benefits presented by the novel cost estimation models in cost planning and control practices. As a dynamic and unique industry, construction industry constantly requires improvements in terms of methods, materials, mechanical and electrical, information technology system, business processes, procurement methods and management techniques (Shamsuddin et al., 2015. Therefore, it is essential to develop an integrated costing method to efficiently keeping up with the constant and rapid changes. An integrated cost method will be able to provide a logical method for accurate determination of a true cost for the project (Shamsuddin et al., 2015).

\section{Knowledge And Expertise}

Lack of knowledge and expertise within the area of IBS construction can lead to financial problems pertaining to construction cost (Abas et al., 2014; Kamar et al., 2012; Tamrin et al., 2016; Zakari et al., 2017). To realize the ideal way of utilizing IBS to its maximum advantage is through educating architects and engineers in a systematic way to integrate design, technology, management, economics, as well as marketing (Aljawadi et al., 2019). Nawi et al (2015) in their study showed that most of the architects and engineers are still unaware of the basic design process to fabricate, connect, and install the elements of IBS in Malaysia. This could be due to the fact that most of the undergraduate engineering programs in Malaysia concentrate more on the traditional design process rather than IBS (Baharuddin et al., 2016). This results in the engineers and designers are more reluctant to use IBS in their projects and prone towards the conventional construction method. The syllabus of IBS design process in current degree and diploma programs, especially in universities, are very limited. Most of the programme emphasize on the traditional design process and do not focus on the design for pre-stress or precast IBS products (Nawi et al., 2015b).

\section{Communication}

Communication between members, parties, and elements of the construction supply chain are challenging because the background, references and goals of each party are different (Haron et al., 2015). When communication is poor, plans and specifications will lack of clear definition, reworks and incompliance with owners' needs may be expected (Arif and Egbu, 2010). Study conducted by Pozin et al (2019) highlighted 5 major problems that obstruct maximum performance of IBS project which are lack of Information Communication Technology (ICT), impropriated organization structure, poor understanding, lack of commitment, and ineffective communication.

\section{Poor Communication Among Stakeholders}

Meeting objective deliverables can be deterred due to poor collaboration and understanding between stakeholders. Such occurrence became a barrier towards efficient objective deliverables and in such case as discussed by Yunus et al (2019) can be caused by lack of systematic tools to incorporate collaboration among stakeholders. Strategies must be laid-down beforehand to ensure smoothness of communication among stakeholders and such strategies must be well integrated as an approach to assist designers (Yunus et al., 2019).

\section{Training}

IBS requires workers to be versatile in terms of their job scope. Under the IBS system, the demand for on-site manual labours such as carpenters, bar benders, and concreters becomes less. This is due to higher demand for machine-oriented skills, both on sites and in factories which lead to the need of acquiring human resources (Zakaria et al., 2017). The quality of training is essential in improving the skill level of workforce at all levels (Rashidi et al., 2017). Restructuring of human resources within organization need to be aligned with intensive IBS skills such as system integrating or assembling (Arif et al., 2012; Zakaria et al., 2017). This requires a tremendous education and training effort, particularly for construction practitioners who are involved in on site activities such as handling, positioning, and erecting the prefabricated components (Rashidi et al., 2017).

\section{Government Policies}

Nawi et al (2012) also confirmed that Malaysian Government policy is a critical factor that heavily influence the promotion of new techniques or products especially in the construction sector. In addition, the findings also showed that companies and agencies usually update their policies aligning with the government policy pertaining to IBS implementation in order to avoid any issues such as redundancies or delays in project delivery. The government policies are considered as the most important factor in enabling the construction teams to work in an integrated and collaborative manner (Nawi et al., 2012). Effective decision-making process strongly depends on government policies to be aligned with the vision and mission of the organization.

\section{Integration Of Resources}

The team brings together various skills and knowledge, and removes the traditional barriers between those with responsibility for design and construction in a way which improves the effective and efficient delivery of the project. Flexibility in prefabrication networks is increased by the means of process integration and cross-training multi-skilled resources as production networks will be able to 
dynamically address variability in demand and resource availability (Arashpour et al., 2018). Multi-skilled resources' priority is to undertake their own operations to maintain the network logic.

\section{Team Integration}

Construction industry is well-known as complex, with its very essence, based on one-off projects and temporary relationships (Nawi et al., 2014). This situation will significantly affect the flow of communication and coordination process among team's members thus contributes to adversarial relationship. 'conflicts, inconsistencies and mismatches' between all of project team members which is possibly due to simple misunderstandings or assumptions problem is mainly caused by the current construction traditional practice (Nawi et al., 2014; Nawi et al., 2011). Key towards a successful team integration in IBS as highlighted in study conducted by Nawi et al (2011):
1. Personal Working Attitude
2. Team accountability
3. Team base organization
4. Management of leadership
5. Transparent Communication
6. Policy
7. Procurement and contracts
8. operational
9. Appropriate technology

\section{Integrated Processes Assessment}

In order for contractor to keep the pace within the industry, innovation initiative is definitely crucial to be able to remain competitive. Yunus et al (2012) further concluded that these factors were related to inappropriate planning decisions, where optimization of IBS implementation is not achievable without a well-defined, decision-making tools. Wrong decision regarding attributes of IBS will result in ultimate alteration of performance, outcomes, as well as quality of the projects (Yunus et al, 2012). Yunus et al (2012) in their study also found that cooperation among key stakeholders is another major issue in IBS approach. Conventional building methods restrict contractors and manufacturers from being involved in the design stage of a project which often results in design changes and a corresponding cost increase. Yunus et al (2012) in their study highlighted several decision-making tools with brief advantages and disadvantages towards optimal IBS implementation.

\section{Management Factors}

The construction of an IBS building has different stages according to type of project and demographic. Five processes of IBS which are initial works, components production at factory, transported to construction site, installation, and finishing (Ismail et al., 2012). The management factors are the niche of the whole supply chain system in industrialised building system (Ismail et al., 2012). It demonstrates a process of controlling and how something is done or used. In contrast to the management process of IBS, the systematic installation of each beam, column, wall or plank is carried out after the successful production of components (Ismail et al., 2012). Management factor according to Ismail et al (2012) consist of:

1. Good working collaboration

2. Effective communication channel

3. Involvement during the design stage

4. Extensive planning and scheduling

5. Risk management

6. Management of supply chain and logistic

7. Top-down commitment

8. Strategy and business approach

9. Industry marketing strategy

10. Environmentally friendly methods

Study conducted in the IBS construction industry by Jabar et al (2019) showed that effective management contribute positively towards performance of construction which can be efficiently implemented and monitored through each phase of project specifically. The phases of project are that of initial phase, planning phase, implementation phase, monitoring phase, and closing phase. The phases itself is the management being implemented, but through increase of management practice within each phase shows occurrence of additional competence besides the intended competence set beforehand (Jabar et al., 2019).

\section{Lean Construction}

Lean strategies have been proven effective in improving productivity levels (i.e., by eliminating wastes from the process) and profit (Nahmens and Ikuma, 2012). The implementation of lean strategies tends to improve the workplace, thus ensuring the health and well-being of the workforce with better layouts and organized workstations, reducing the exposure to workplace hazards. Lean construction strategies provide an excellent platform to improve not only the economic dimension, but also the social and environment 
dimensions in homebuilding, primarily by improving the delivery processes of sustainable IBS construction (Nahmens and Ikuma, 2012)

\section{Contractors' Satisfaction}

Contractors' satisfaction with the merits of IBS can significantly influence the performance of an IBS project (Yunus et al., 2016). Yunus et al (2016) examined the relationship between contractors' satisfaction and project performance, and showed that satisfied contractors in the benefits of IBS has direct influence on project performance in terms of Having a clear understanding on the environmental regulations and requirement by the local authorities will enables the contractor to deliver the project with less rework. Interestingly, safety performance not only benefits the contractors in term of social but also has a potential to minimize the overall construction cost. IBS components were produced offsite and can immediately install as a structural element once delivered to the construction site. The numbers of debris or waste is also very small. This will reduce additional cost for unnecessary works such as site clearing and storage for construction materials. In Malaysia, the main factor for the delayed completion of construction projects is due to poor performance by the contractors (Yunus et al., 2016). In most cases, the contractors' satisfaction in project implementation is neglected. it is vital to investigate the contractors' satisfaction in order to ensure their performance is at the optimum level. Their motivation and cooperation should be investigated to allow them working in a conducive working environment. Poor contractor satisfaction hindered a performance-enhancing environment and degrading the quality of project outcomes. In this context, there is a need for better understanding of the satisfaction measurement for contractors to enhance the productivity for IBS implementation. Integration among the participants is important to ensure the successful of IBS projects. An effective collaboration on the key attributes and evaluation of successful factors can help the projects meet the project objectives as well as increase participant's satisfactions (Yunus et al., 2016). Motivation and cooperation among the participants can be improved by enhancing their satisfaction level. It will increase the efficiency of communication at the project and management level. At the same time, any problems that occur in the construction activity can be easily resolved.

\section{Utilization Of Software}

The software experts claimed that current BIM software is not that great for assemblies. Currently, existing software does not allow, practically and in any automated form, identification of opportunities for off-site construction more than 'in the old document and drawing-based design' and construction process. However, BIM has the potential to promote off-site construction by identifying repetition, which will enable greater cost-saving through mass customization (Vernikos et al., 2014). BIM should 'be more about information, productivity, re-usability and one input - many outputs but there should be more automation within the model to identify and promote areas for further cost reduction from economies to scale through off-site construction'.

\section{Market Factor}

The market for prefabricated components includes two categories: the upstream supply chain market and the terminal consumption market. The upstream supply chain for prefabricated products engages various industrial sectors, such as mold producers and precast component manufacturers. Upstream sectors and materials could be inadequate, or various supply chain groups could face conflicts and poor collaboration. In fact, these conditions reflect the fragmented structure of the prefabrication industry, which is common in developing countries such as Malaysia. Owners encounter difficulties in finding and establishing effective collaboration among skilled contractors or suppliers and consultants in the local market who could implement IBS (Luo et al., 2015). Therefore, the quality of prefabricated components and buildings cannot be guaranteed because of the poor labour skill and collaboration. Furthermore, the oligopoly of prefabricated techniques possessed by a few firms presents an opportunity for these firms to raise production price.

\section{On-Site Management}

Construction quality is largely based on acquired experience. Without this experience, all project stakeholders, including clients, contractors, suppliers, and consultants, work on a trial-and-error basis (Luo et al., 2015). This practice presents the risks of poor quality, safety-related accidents, time delays, cost overruns, and other risks. Due to lack of experience, clients are not confident to adopt IBS. Furthermore, the standardized procedures and production lines for producing components present no flexibility for adapting and responding to changes and uncertainties.

\section{Technical Factor}

Typical technical factors are associated with implementing IBS are "errors and defects due to poor design ability of designers", "poor skills in assembling and hoisting precast components on site," and "incompetence of technology and equipment" (Luo et al., 2015). These factors contribute to time delays and poor construction quality. "Incompetence of technology and equipment" is also considered as a typical technical factor in implementing industrialized building practices.

\section{Payment Issues}

Payment can be defined as a transaction sum of money for the purpose of good sold or service rendered. In construction, payment is referring to monetary consideration for the contractor's performance or work done (Dzulkalnine et al., 2017). Nawi et al (2017) in their study found that the Malaysian construction has been plagued with payment issue in long time period and has negatively 
affect construction players particularly contractor. Flow of payment in construction project is a crucial element in order to achieve the objective of the project. Any delay in cash flow will have major influence such as project delay toward progress of the construction project. Compared to conventional method, payment issues have significantly affected productivity and development progress of Industrialized Building System project (Dzulkalnine et al., 2017). As mentioned above, the IBS system is based on prefabrication process which contractors need to purchase construction component from manufactures and this concept required them to have a strong cash flow. Payment issues not only affect the construction project itself, but also lead the company into liquidation and influenced the profitability. In general, a payment issue is hierarchical problem which affect all the construction players and overall construction process (Dzulkalnine et al., 2017). For example, one of the chronologies in payment issues, if the clients have difficulties to make payment to the main contractor and may lead to contractor unable to pay their sub-contractor in turn, the sub-contractor failed to make payments to supplier and negatively affect project progress.

\section{Employee Empowerment}

Strategies to increase labour productivity in construction are essential; as the comparative cost of human resources rises there is an increasing need to develop systems of work that lead to a growth in productivity (Alazzaz and Whyte, 2015). However, measuring such strategies is challenging. Despite the apparent simplicity of the definition of labour productivity, this indicator is difficult to track consistently, largely because of the complexity of quantifying and comparing diversified outputs in construction (Alazzaz and Whyte, 2015). The link between productivity and empowerment is the presumption that empowered employees perform better than those less empowered, such that, greater productivity arises from the empowered employee's superior ability to resolve problems at the operations level, without the delay needed to contact line-managers leading to greater productivity via localised workplace decisions that increase individual/organisational performance (Alazzaz and Whyte, 2015). Reliance on labour-intensive activities means that optimal labour productivity is a key performance indicator (Alazzaz and Whyte, 2015). With productivity being closely related to commercial viability it is necessary to better understand the factors that may foster or hamper growth in this area such as: diminishing levels of specialist skills; non-optimal craftsmanship; and, poor management practices (Alazzaz and Whyte, 2015).

\section{Benefits Of IBS}

Implementation of IBS can greatly reduce dependencies of foreign labours in this country where involvement of human interface can be reduced exponentially. Construction method of IBS highlights the ability to manufacture under industrialized production technique in a controlled environment, transported, and then installed in the site with minimum additional site workers which represents a rapid alternative construction (Taherkhani and Saleh, 2019). Rapid alternative method of constructing is the best alternative and has been taken into high consideration by construction industries worldwide (Taherkhani and Saleh, 2019). Productivity and quality also became one of the most influential traits for contractors to choose IBS over traditional method of construction where manufacturing of building components were done within a controlled environment (Azman et al., 2012). Azman et al (2012) further highlighted the benefits from implementation of IBS in the construction industry as being environmentally friendly where waste generation will be significantly diminished. It is because the manufacturing of components will be made off-site and according to specific design that will optimize usage of resources. The ranking of IBS from the most beneficial to the least beneficial characteristics (Azman et al., 2012) are as shown:

$\begin{array}{ll}\text { 1. } & \text { Minimal wastage } \\ 2 . & \text { Cleaner environment } \\ 3 . & \text { Less site materials } \\ 4 . & \text { Reduction of site labour } \\ 5 . & \text { Controlled quality } \\ 6 . & \text { Faster project completion } \\ 7 . & \text { Neater and safer construction sites } \\ 8 . & \text { Lower total construction costs }\end{array}$

\section{CONCLUSION}

From a total of 11376 documents generated using 'Scopus' search engine, 73 were usable after careful filtering steps were taken. Synthesis were done on all 73 documents and managed to generate 16 influencing factors towards IBS project performance with a total of 48 articles. The other remaining articles contributed towards benefits of IBS implementation in comparison with conventional method of construction as well as defining IBS in the introduction.

\section{Factors Influencing Successful Ibs Implementation}

Most literature in-regards of IBS discussed mainly on all causes why IBS cannot be implemented or why IBS cannot perform very well. Through systematic review, this paper managed to extract factors that according to studies conducted previously by researchers can directly influence well-being of IBS project performance. By going through all 73 articles, this paper synthesized a total of 16 influencing factors that can be utilized in order to increase performance of IBS projects. At the same time, this paper also contributes towards benefits of IBS project utilization in comparison with traditional construction method. The most discussed factor was cost of construction where previous studies done on IBS project showed positive result of costing towards the performance of IBS. Among all 16 factors, cost of construction is the most influential factor in order for contractor to increase performance of a particular IBS project. Throughout the years of IBS implementation, studies showed cost of construction to have significant impact towards IBS performance. 
Cost of construction between conventional construction and IBS construction differs greatly due to the distinguish processes of IBS from traditional way of constructing. IBS requires bigger start-off that involves much expensive plants, machineries, materials, and so on but be beneficial through that in aspects traditional method of constructing cannot efficiently provide.

The second most influential factor is knowledge and expertise of IBS project. Based on studies done in the past, IBS require additional and specific type of knowledge and expertise in order to ensure efficient delivery of project. Before diving and striving towards an IBS construction project, being knowledgeable with the suitable expertise to guide the way is crucial so that IBS project can prosper very well in terms of performance. Having only the know-how does not cut it in the effort to deliver a high-performing IBS project performance. Knowledge can be obtained from various sources and two main source of IBS knowledge and expertise are from experience, as well as proper training. The third ranked factor was communication. Communication serve performance of IBS project almost as same as how it serves conventional method of constructing. Communication serves the same purpose for both methods of construction but weighs more within an IBS construction environment. IBS construction involves more routine procedures and processes than that of a traditional construction method which significantly causes communication to be a bit complex.

The importance of training weighs the same with the two different construction methods. Training factor in this paper refers to training of employee or mainly training of execution personnel. It is important and crucial to not just have an expert and knowledgeable leader or manager, but also a well-trained, versatile workforce in order to significantly boos performance. Government policies scored fifth in the rank of influential factors. Government being out from top 3 factors is actually quite surprising especially in the case of Malaysia's IBS construction environment. In Malaysia particularly, government plays a major role in enforcing strict implementation of IBS as well as providing support platform for IBS practitioners in terms of financial. Government is also the only entity in Malaysia that has the authority to make amendment on policies of IBS in Malaysia which technically making government as supposedly one of the most influential factor that can directly affect how well a particular IBS project performs. Integration of resources refers to the contractors being able to fully make use of all its resources efficiently. Ability to integrate resources across the construction life cycle is categorized as one of influential factor affecting IBS performance. Even though the factor itself sounded complex and crucial, but from the systematic review, it has been found that integration of resources is not as important as having financially prepared and knowledgeable. The same goes to government policies and all other factors derived from this systematic review. The other factors such as lean construction, contractor's satisfaction, utilization of software, market factor, technical factor, on-site management, integrated assessment processes, management factor, payment issues, and employee empowerment were discussed each in 1 article from all 73 articles in this systematic review.

In conclusion, through this systematic review, 16 influencing factors were derived from 73 articles with 6 of them being highly influential than the other based on the most discussed factors from all articles. The 6 highly influential factors are cost of construction, knowledge and expertise, training, communication, government policies and integration of resources. These 6 factors are the most discussed factors in 73 total articles that have significant impact towards IBS project performance. In order for a particular IBS project to efficiently perform, these are the 6 critical factors for contractors to utilize. Even so, there is still no holistic environment that can accurately shape towards maximum level of performance in reality of IBS construction. Each project is a unique endeavour undertaken through a set of tasks to achieve objective and deliverables. Uniqueness of a particular project is also a factor to be taken into careful consideration before applying measures. In other way, different project may incur different influential factors and some might be fatal in some ways while some may actually boost performance. Based on this review, 16 factors that can influence performance of IBS project were derived. Among all 16, 6 were deemed as most influential than the remaining 10 factors.

\section{ACKNOWLEDGEMENT}

The authors would like to acknowledge and appreciate Universiti Malaysia Pahang for funding this study through RDU1703296.

\section{REFERENCES}

Abas, A., Hanafi, M. H., \& Ibrahim, F. A. (2014). Assessing the Malaysian architects' understanding of industrialized building system concept and implementation. International Journal of Applied Engineering Research, 9(1), 101-116.

Akmam, S. Z., S., Gajendran, T., Rose, T., \& Brewer, G. (2018). Contextual, structural and behavioural factors influencing the adoption of industrialised building systems: a review. Architectural Engineering and Design Management, 14(1-2), 3-26. doi:10.1080/17452007.2017.1291410

Alazzaz, F., \& Whyte, A. (2015). Linking employee empowerment with productivity in off-site construction. Engineering, Construction and Architectural Management, 22(1), 21-37. doi:10.1108/ECAM-09-2013-0083

Aljawadi, A. S., Marsono, A. K., \& Ismail, C. R. (2019). Ductility of reinforced concrete sub frame for industrialized building system. Jurnal Teknologi, 81(2), 1-9. doi:10.11113/jt.v81.11452

Arashpour, M., Wakefield, R., Abbasi, B., Arashpour, M., \& Hosseini, R. (2018). Optimal process integration architectures in off-site construction: Theorizing the use of multi-skilled resources. Architectural Engineering and Design Management, 14(1-2), 4659. doi:10.1080/17452007.2017.1302406

Arif, M., \& Egbu, C. (2010). Making a case for offsite construction in China. Engineering, Construction and Architectural Management, 17(6), 536-548. doi:10.1108/09699981011090170

Arif, M., Goulding, J., \& Rahimian, F. P. (2012). Promoting off-site construction: Future challenges and opportunities. Journal of Architectural Engineering, 18(2), 75-78. doi:10.1061/(ASCE)AE.1943-5568.0000081 
Azman, M. N. A., Ahamad, M. S. S., Hamid, Z. A., Gomez, C. P., Kamar, K. A. M., Hilmi, N. D., . . Ismail, Z. (2012). The selection of IBS precast manufacturing plant in Malaysia using GIS. Malaysian Construction Research Journal, 10(1), 77-90.

Baharuddin, M. N., Bahardin, N. F., Zaidi, M. A., Lokman, I., \& Nawi, M. N. M. (2016). A barriers and challenging criteria of IBS formwork: A current scenario amongs stakeholder. Revista Tecnica de la Facultad de Ingenieria Universidad del Zulia, 39(9), 14-21. doi:10.21311/001.39.9.03

Dzulkalnine, N., Azman, M. N. A., Bing, K. W., \& Hamid, Z. A. (2017). Payment issue of industrialised building system (IBS) in Malaysian construction industry. Malaysian Construction Research Journal, 2(Special Issue 2), 36-47.

Haron, A. T., Marshall-Ponting, A. J., Zakaria, Z., Nawi, M. N. M., Hamid, Z. A., \& Kamar, K. A. M. (2015). An industrial report on the Malaysian building information modelling (BIM) taskforce: Issues and recommendations. Malaysian Construction Research Journal, 17(1), 21-36.

Ismail, F., Yusuwan, N. M., \& Baharuddin, H. E. A. (2012). Management Factors for Successful IBS Projects Implementation. Procedia - Social and Behavioral Sciences, 68, 99-107.

Jabar, I. L., Abdul-Aziz, A. R., Suresh, S., Renukappa, S., \& Enshassi, A. (2019). A project management competency framework for industrialised building system (IBS) construction. International Journal of Technology, 10(4), 657-666. doi:10.14716/ijtech.v10i4.2773

Kamar, K. A. M., Azman, M. N. A., \& Nawi, M. N. M. (2014). IBS survey 2010: Drivers, barriers and critical success factors in adopting industrialised building system (IBS) construction by G7 contractors in Malaysia. Journal of Engineering Science and Technology, 9(4), 490-501.

Kamar, K. A. M., Hamid, Z. A., Ghani, M. K., Rahim, A. H. A., Zain, M. Z. M., \& Ambon, F. (2012). Business strategy of large contractors in adopting industrialised building system (IBS): The Malaysian case. Journal of Engineering Science and Technology, 7(6), 774-784.

Lee, C. K., Yiu, T. W., \& Cheung, S. O. (2016). Selection and use of Alternative Dispute Resolution (ADR) in construction projects Past and future research. International Journal of Project Management, 34(3), 494-507.

Luo, L. Z., Mao, C., Shen, L. Y., \& Li, Z. D. (2015). Risk factors affecting practitioners' attitudes toward the implementation of an industrialized building system a case study from China. Engineering, Construction and Architectural Management, 22(6), 622-643. doi:10.1108/ECAM-04-2014-0048

Musa, M. F., Yusof, M. R., Mohammad, M. F., \& Samsudin, N. S. (2016). Towards the adoption of modular construction and prefabrication in the construction environment: A case study in Malaysia. ARPN Journal of Engineering and Applied Sciences, 11(13), 8122-8131.

Nahmens, I., \& Ikuma, L. H. (2012). Effects of lean construction on sustainability of modular homebuilding. Journal of Architectural Engineering, 18(2), 155-163. doi:10.1061/(ASCE)AE.1943-5568.0000054

Nasir, N. M., Nawi, M. N. M., Rahim, M. K. I. A., Bahaudin, A. Y., \& Tapa, A. (2016). A review of delay factors in Malaysian industrialized Building System (IBS) construction project. ARPN Journal of Engineering and Applied Sciences, 11(16), 9868-9873.

Nawi, M. N. M., Azman, M. N. A., Baluch, N., Kamar, K. A. M., \& Abd Hamid, D. Z. (2015). Study on the use of industrialised building system in Malaysian private construction projects. ARPN Journal of Engineering and Applied Sciences, 10(17), 7368-7374.

Nawi, M. N. M., Lee, A., Azman, M. N. A., \& Kamar, K. A. M. (2014). Fragmentation issue in Malaysian industrialised building system (IBS) projects. Journal of Engineering Science and Technology, 9(1), 97-106.

Nawi, M. N. M., Lee, A., Kamar, K. A. M., \& Hamid, Z. A. (2011). A critical literature review on the concept of team integration in industrialised building System (IBS) project. Malaysian Construction Research Journal, 9(2), 1-17.

Nawi, M. N. M., Lee, A., Kamar, K. A. M., \& Hamid, Z. A. (2012). Critical success factors for improving team integration in Industrialised Building System (IBS) construction projects: The Malaysian case. Malaysian Construction Research Journal, 10(1), 44-62.

Nawi, M. N. M., Shaharanee, I. N. M., Hashim, K. F., Azman, M. N. A., \& Ibrahim, S. H. (2015). Qualitative Analysis on the Barriers of Industrialised Building System (IBS) Uptake in Malaysian Construction Projects. Advanced Science Letters, 21(6), 21342138. doi:10.1166/asl.2015.6233

Pozin, M. A. A., Nawi, M. N. M., Azman, M. N. A., \& Lee, A. (2017). Improving communication in managing industrialised building system (IBS) projects: Virtual environment. Malaysian Construction Research Journal, 2(Special Issue 2), 1-13.

Pozin, M. A. A., Nawi, M. N. M., Mydin, M. A. O., Riazi, S. R. M., \& Imran, A. (2019). An ability of Whatsapp usage in industrialised building system (IBS) construction project. International Journal of Interactive Mobile Technologies, 13(4), 188-197. doi:10.3991/ijim.v13i04.10548

Rashidi, A., \& Ibrahim, R. (2017). Industrialized construction chronology: The disputes and success factors for a resilient construction industry in Malaysia. Open Construction and Building Technology Journal, 11, 286-300. doi:10.2174/1874836801711010286

Rubio-Romero, J. C., Suárez-Cebador, M., \& Abad, J. (2014). Modeling injury rates as a function of industrialized versus on-site construction techniques. Accident Analysis and Prevention, 66, 8-14. doi:10.1016/j.aap.2014.01.005

Shamsuddin, S. M., Zakaria, R., Mohamed, S. F., Saleh, A. L., Utomo, C., Majid, M. Z. A., \& Yahya, K. (2015). Developing methodology for cradle to grave cost planning for industrialised building system (IBS) In Malaysia. Jurnal Teknologi, 77(16), 37-42. doi:10.11113/jt.v77.6397

Taherkhani, R., \& Saleh, A. L. (2019). Awareness and prevalence of Industrialized Building System (IBS) in Iran. Jurnal Teknologi, 81(6), 13-23. doi:10.11113/jt.v81.13364

Tamrin, N., Nawi, M. N. M., \& Nifa, F. A. A. (2016). Readiness in knowledge and ability for implementation of industrialised building system (IBS) in Malaysian construction industry. Revista Tecnica de la Facultad de Ingenieria Universidad del Zulia, 39(9), 47-53. doi:10.21311/001.39.9.07 
Vernikos, V. K., Goodier, C. I., Broyd, T. W., Robery, P. C., \& Gibb, A. G. F. (2014). Building information modelling and its effect on off-site construction in UK civil engineering. Proceedings of Institution of Civil Engineers: Management, Procurement and Law, 167(3), 152-159. doi:10.1680/mpal.13.00031

Xue, H., Zhang, S., Su, Y., Wu, Z., \& Yang, R. J. (2018). Effect of stakeholder collaborative management on off-site construction cost performance. Journal of Cleaner Production, 184, 490-502. doi:10.1016/j.jclepro.2018.02.258

Yip, C. C., Wong, J. Y., \& Hor, K. W. (2019). A nonlinear finite element analysis of precast industrialised building system beam under flexural test. Jurnal Teknologi, 81(3), 73-82. doi:10.11113/jt.v81.12486

Yunus, R., Abdullah, A. H., Yasin, M. N., Masrom, M. A. N., \& Hanipah, M. H. (2016). Examining performance of Industrialized Building System (IBS) implementation based on contractor satisfaction assessment. ARPN Journal of Engineering and Applied Sciences, 11(6), 3776-3782.

Yunus, R., Hamid, A. R. A., \& Noor, S. R. M. (2019). An integrated approach for sustainability in the application of Industrialised Building System (IBS). International Journal of GEOMATE, 17(61), 115-121. doi:10.21660/2019.61.4810

Yunus, R., \& Yang, J. (2012). Critical sustainability factors in industrialised building systems. Construction Innovation, 12(4), 447-463. doi:10.1108/14714171211272216

Zakari, I., Awal, A. S. M. A., Zakaria, R., Abdullah, A. H., \& Hossain, M. Z. (2017). Application of industrialized building system: A case study in Kano State, Nigeria. International Journal of GEOMATE, 13(39), 80-86. doi:10.21660/2017.39.19788

Zakaria, S. A. S., Majid, T. A., \& Nazri, F. M. (2017). Adoption of industrialised building system (IBS): Exploring competitive advantages from a technology valuation perspective in northern Malaysia. Malaysian Construction Research Journal, 22(2), 1-17. 


\section{AUTHORS' BIOGRAPHY}

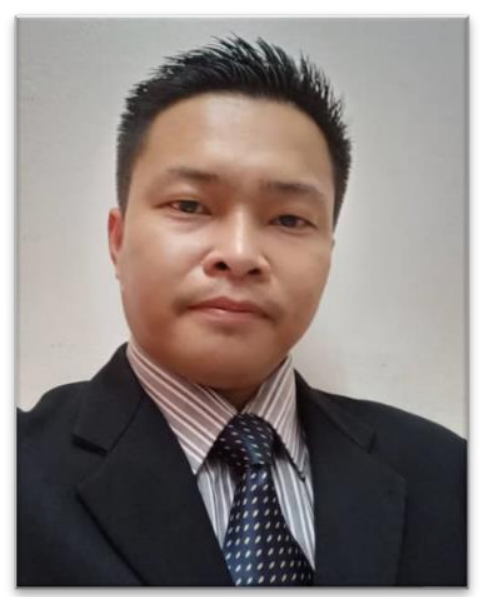

Yusmin Jaffar is an administrative executive assistant under Industrial and Community Network (ICoN) department in University Malaysia Pahang. Yusmin Jaffar has a bachelor degree in Project Management with honors and is currently a full-time research-based postgraduate student pursuing master's degree in University Malaysia Pahang.

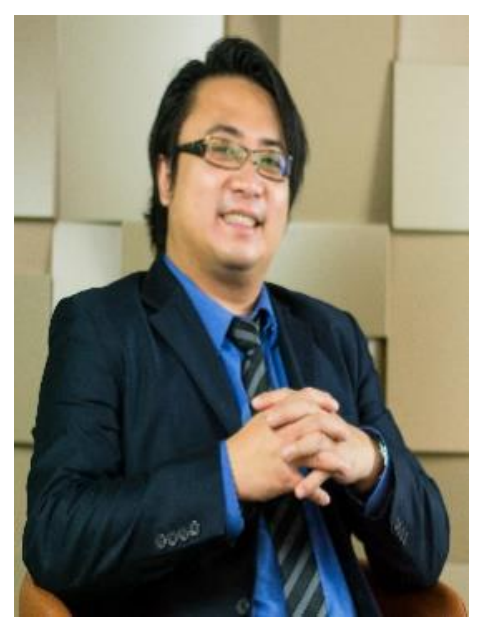

Dr. Chia Kuang LEE is a Senior Lecturer in Project Management, with more than 10 years of experience in R\&D works specifically in construction management and project management. He has worked as the Head of Program for Project Management Degree Course in Universiti Malaysia Pahang, and has been recognized with several teaching and research awards during his career, such as the the Most Promising Academician Award 2018. Dr. Lee is currently the Head of Research Cluster (Project Management). Dr. Lee has managed several research projects as research leader, overseen the development of project management degree program, and pioneered the course towards full PMI GAC accredited status by the Project Management Institute (PMI), USA. He has several professional qualifications and credentials, such as :Certified in Quantitative Risk Management (CQRM) by International Institute of Professional Education \& Research (IIPER), Project Management Professional (PMP) by Project Management Institute (PMI), Certified as Professional Technologist by the Malaysia Board of Technologists (MBOT), and Train the Trainers (TTT) by HRDF. Dr. Lee has a Bachelor Degree in Quantity Surveying (B.Q.S) and Master of Science (MSc Construction Contract Management) from Universiti Teknologi Malaysia. He earned a PhD in Civil Engineering from The University of Auckland, New Zealand in 2017, focusing mainly on the field of Construction Alternative Dispute Resolution (ADR) method. 